\title{
Otizm Spektrum Bozukluğu Tanısı Olan Çocuklarda Terapötik At Binme Aktivitelerinin Yaşam Kalitesi ve Motor Performans Üzerine Etkisi
}

\section{The Effect Of Therapeutic Horseback Riding On The Quality Of Life And Motor Performance In Children Diagnosed With Autism Spectrum Disorder}

\author{
Araştırma Makalesi
}

\author{
'Selçuk AKPINAR, 'Kürşat ÖZCAN, ${ }^{2}$ Gonca ÖZYURT, ${ }^{3}$ Çağla DiNSEVER \\ 1 Nevşehir Hacı Bektaş Veli Üniversitesi, Eğitim Fakültesi, Beden Eğitimi ve Spor Eğitimi Bölümü \\ 2 İzmir Katip Çelebi Üniversitesi, Tıp Fakültesi, Dahili Tıp Bilimleri Bölümü, Çocuk ve Ergen Ruh Sağlığı ve Hastalıkları \\ A.B.D. \\ 3 Ankara Numune Eğitim ve Araştırma Hastanesi, KBB Poliklinikleri
}

\section{öz}

$\mathrm{B}$ çalışmadaki amaç Otizm Spektrum Bozukluğu (OSB) tanısı olan çocuklarda terapötik at binme aktivitelerinin yaşam kalitesi ve kollar ile yapılan uzanma hareketi sırasındaki motor performans üzerine etkisinin araştırılmasıdır. Bu amaç doğrultusunda yaşları 8 ve 13 arasında değişen (Ort ${ }_{\text {yas }} \pm$ Ss: $=9.66 \pm 1.61$ ) ve OSB tanısı olan 12 çocuk (5 kız 7 erkek) çalışmaya katılmıştır. Çocuklar 8 hafta boyunca haftada 1 saat terapötik at binme aktivitelerine katılmışlardır. Terapötik at binme aktivitelerinin başlangıcından önce ve bitiminden hemen sonra çocuklarda yaşam kalitesinin ebeveyn değerlendirmeleri ve üst ekstremite motor performans ölçümleri yapılmıştır. Yaşam kalitesi değerlendirmesi için Çocuklar İçin Yaşam Kalitesi ölçeği ebeveyn formu kullanılmıştır. Bu ölçekteki 2

\section{A B S T R AC T}

The purpose of this study was to investigate the effect of therapeutic horseback riding on the quality of life and motor performance in children diagnosed with autism spectrum disorder. For this purpose, 12 children ( 5 girls and 7 boys) diagnosed with autism spectrum disorder between the ages of 8 and 13 (Mean $_{\text {age }} \pm$ Sd: $9.66 \pm 1.61$ ) were participated to the study. They joined an 8-week and 1-hour session per week therapeutic horseback riding training. The assessment of quality of life and motor performance measurements during arm reaching movements were performed one day before and one day after the therapeutic horseback riding training sessions. To assess the quality of life, the pediatric quality of life scale parent form was used. We assessed the two sub-dimensions of that scale, the 
alt boyut olan fiziksel sağlık ve psikososyal sağlık toplam puanları değerlendirilmiştir. Motor performans ölçümlerinde çocuklardan belli bir mesafede olan hedeflere kolları ile uzanmaları istenmiş ve horizontal düzlemde işaret parmağının hareketleri 2 boyutlu olarak kayıt edilmiştir. Sadece 4 çocuk motor performans testine katılmıştır. Yapılan kinematik analiz sonucunda çocukların kolları ile hedeflere ne kadar doğru ve doğrusal ulaştıkları hesaplanmıştır. İstatistik analiz sonucunda terapötik at binme aktivitelerinden sonra yaşam kalitesinde gelişme gözlemlenmiştir. Motor performans ölçümlerinde de bir gelişme olmasına karşın, bu gelişme istatistiksel olarak anlamlı seviyeye ulaşmamıştır. Terapötik at binme aktivitelerinin OSB tanısı olan çocuklarda alternatif bir rehabilitasyon yöntemi olarak kullanılması önerilmektedir

\section{Anahtar Kelimeler}

Rehabilitasyon, Otizm Spektrum Bozukluğu, Terapötik At Binme, Yaşam Kalitesi, Motor Performans total of physical health and psychosocial health. For the motor performance measurements, children were asked to reach a target with either hand and upper extremity kinematics during their reaching movements were recorded in horizontal plane. Accuracy in pointing and hand linearity were two parameters to assess motor performance in children. Only four children participated in the motor performance tests. The statistical analysis showed improvements on the quality of life following the 8-week therapeutic horseback riding training. Even though there was an improvement in the motor performance test from the pre- to post-test, this improvement did not reach the significant level. Therapeutic horseback riding is therefore recommended as an alternative rehabilitation treatment for the children diagnosed with autism spectrum disorder.

\section{Key Words}

Rehabilitation, Autism Spectrum Disorder, Therapeutic Horseback Riding, Quality of Life Scale, Motor

Performance

\section{Giriş}

Özellikle gelişmiş toplumlarda tıbbi tedavilerin yanında yardımcı aktiviteler genel olarak tüm hastalık çeşitlerinde kullanılmaktadır (Wang ve diğ., 2007). Bu aktivitelerden birisi de "Terapötik At Binme" aktiviteleridir. Yardımcı tedavi olarak terapötik at binme aktivitelerinin, fiziksel, fizyolojik, psikolojik ve sosyal yönden insan sağlığını olumlu yönde etkilediği (Borgi ve diğ., 2016; Bronson ve diğ., 2010; Freund ve diğ., 2011), fakat etki derecesinin tam olarak bilinmediği bir gerçektir. Terapötik at binme, birçok engelli grubunda at ile birlikte yapılarak kullanılan bir yardımcı tedavi tekniğidir. Bu tekniğin çok farklı açılardan dikkat eksikliği ve hiperaktivite bozukluğu (Katcher ve Wilkins, 1988), şizofreni (Barak ve diğ., 2001), serabral palsi (Yıldırım Şık ve diğ., 2012), down sendromu (Copetti ve diğ., 2007) gibi hastalıklarda dikkat süresi, denge, postür, vücut kontrolü ve sosyal becerilerde fayda sağladığı gözlemlenmiştir. Terapötik at binmenin faydalı olarak görüldüğü engelli gruplarından bir tanesi de otizm spektrum bozukluğudur (O'Haire, 2013). Otizm spektrum bozukluğu, 3 yaşından önce gözlemlenebilen ve yaşam boyu devam edebilen sosyal etkileşim ile birlikte iletişimi de olumsuz yönde etkileyen, kişiye özgü ve tekrarlanan davranışlara yol açan bir rahatsızlıktır (American Psychiatric Association [APA], 2013). Otizm spektrum bozukluğunun özellikle son yıllarda artış gösterdiği görülmektedir. Bundan 40 yıl öncesinde 4/10000 oranında görülmesine karşın son yıllarda bu oranın 30-40 kata kadar arttığı tespit edilmiştir (Rutter, 2005). Sosyal etkileşim ve iletişimdeki önemli olumsuzluklarının yanında, otizm spektrum bozukluğu tanısı olan çocuklar duyuları bütünleştirme ve motor fonksiyonlar açısından da zorluk yaşamaktadırlar (Ayres ve Tickle, 1980; Smith, 2004). Bu durum özellikle çocukların okuldaki ve çevrelerindeki aktivitelere katımalarını engelleyebilmektedir.

Duyuların bütünleştirilmesi ile ilgili otizm spektrum bozukluğu tanısı olan çocuklardaki problemlerin iki şekilde olduğu görülmüştür (Ayres, 1979). Bunlardan birincisi, çevreden gelen duyusal bilginin düzenlenememesi ve kayıt edilememesinden kaynaklanmaktadır. Bazı otizm spektrum bozukluğu tanısı olan çocukların duyusal bilgilerin belirlenmesinde, yönlendirilmesinde veya algılanmasında problem yaşadıkları görülmektedir. Bunun sonucunda da bazı durumlarda gereğinden fazla 
veya gereğinden az tepki vermeleri gözlemlenmektedir (Case-Smith, 1991). İkinci problem ise, gelen duyusal uyarının anlamlandırılamaması ve düzgün bir şekilde organizasyonunun yapılamamasından kaynaklanan duyuların ayırt edilememesi ve algılanamamasıdır (CaseSmith, 1991). Yani aynı anda verilen görsel ve işitsel uyarının farklı şekilde yorumlanması ve bu uyarıların bütünleştirilememesidir. Motor planlama, duygusal davranış gelişimi ve görselalgısal fonksiyonların da özellikle duyuların ayrıştırılması ve algılanmasından kaynaklanan problemlerden etkilenebildiği belirtilmiştir (Mulligan, 1998). Motor bozukluklar dikkate alındığında, otizm spektrum bozukluğu tanısı olan çocukların sıklıkla sıra dışı vücut postürü ve hareketlerine ve bunun yanında motor gelişimle ilgili becerileri doğal sıralamasının dışında edindiklerine rastlanmaktadır (Teitelbaum ve diğ., 1998). Ayrıca otizm spektrum bozukluğu tanısı olan çocukların zayıf motor yeterliliği (Smith, 2004), zayıf postür korunumu (Koomar ve Bundy, 2002) ve vücut hareketlerindeki akıcılığın yetersizliğini tespit eden araştırmalar mevcuttur (Reeves ve Cermak, 2002).

Geleneksel olarak engelli bireylerin tedavi ve terapisi kapalı mekanlarda gerçekleşmektedir. Bu durum zamanla hem terapist hem de hasta için terapinin sıkıcı olmasına yol açmaktadır (Cherng ve diğ., 2004). Bu sıkıcı durumun ortadan kaldırılması için alternatif terapötik seçenekler ortaya çıkmıştır. Bunlara su aktiviteleri ve terapötik at binme aktiviteleri örnek olarak verilebilir. Terapötik at binmenin en önemli faydaları arasında çocukların duyu-motor tecrübelerini arttırmak sayılabilir (Snider ve diğ., 2007). Bu da iki şekilde görülmektedir. Birincisi atın vücut hareketlerine uyum sağlamak amacıyla yapılan pasif hareketlerdir (atın üzerinde dengesini sağlamak, tırıs giden ata uymak için oturup kalkmak gibi). íkincisi ise atın hareketinden bağımsız olarak farklı hedef davranışları içeren aktif hareketlerdir (kolları ile dizginleri kullanarak atı yanlara yönlendirmek, at üzerindeyken eline verilen topu ilerdeki potaya giderek atmak gibi). Bu tarzda aktiviteler çocukların temel motor kontrol becerilerinin kazanımına ve istenmeyen vücut hareketlerinin engellenmesine yardımcı olmaktadır (Schmidt ve Lee, 2005). Buradaki temel amaç ise çocukların aktif hareketlerini kolaylaştırmak ve gelişmiş motor becerileri kazanmaları için farklı fırsatlar oluşturmaktır. Bu sayede terapötik at binme; kinestetik, proprioseptif ve vestübüler girdilerin geliştirilmesini sağlamaktadır (Snider ve diğ., 2007). Bu durum da herhangi bir uyarana karşı verilecek uygun tepkilerin geliştirilmesinde önemlidir.

Otizm spektrum bozukluğu tanısı konuIan çocukların özellikle sosyal alanlarda zorluk çektikleri bilinmektedir (APA, 2013). Otizm spektrum bozukluğu tanısı olan çocuklar çoğunlukla sosyal normları anlamada zorluk yaşamaktadırlar. Özellikle hayvanlarla yapılan terapilerin otizm spektrum bozukluğu tanısı olan çocuklarda sosyal fonksiyonları arttırdığı yönünde sonuçlar elde edilmiştir (O'Haire, 2013). O'Haire (2013) tarafından yazılan derleme makalede, hayvanlarla yapılan terapilerin otizm spektrum bozukluğu tanısı olan çocuklarda sosyal etkileşim ile iletişimi arttırdığı ve stresi azalttığı yönünde araştırmalar olduğu belirtilmiştir. Rothe ve diğ. (2005) at ve çocuk arasındaki etkileşimin, sosyalleşme ve öz benlik duygularını arttırdığını bulmuşlardır. Dolayısıyla terapötik at binme aktivitesinin otizm spektrum bozukluğu tanısı olan çocukların sosyalleşme düzeylerini arttırabileceği sonucuna varılabilecektir.

Terapötik at binme aktivitelerinin otizm spektrum bozukluğu tanısı olan çocuklar üzerine sosyal ve psikolojik alanlarda katkı yaptığı ile ilgili çalışmalar olmasına karşın (Bass ve diğ., 2009; Rothe ve diğ., 2005), motor performans parametreleri üzerine etkilerini konu alan araştırmaların sayısı oldukça azdır (Wuang ve diğ., 2010). Özellikle otizm spektrum bozukluğu tanısı olan çocukların günlük işlerini daha verimli ve etkili yapabilmeleri için yaşam kalitelerinin (fiziksel, duygusal, psikolojik gibi) iyileştirilmesinin yanında hareketleri kontrol edebilme seviyelerinin de arttırılması gereklidir. Bunun için motor performans düzeylerinin 
arttırılması yönünde çalışmaların yapılması gereklidir. Dolayısıyla bu çalışmadaki amaç, terapötik at binme aktivitesinin otizm spektrum bozukluğu tanısı olan çocuklarda yaşam kalitesi ve motor performans üzerine olan etkisinin araştırılmasıdır.

\section{YÖNTEM}

Araştırma Grubu: Bu araştırmaya Nevşehir ilinde merkez ilçesinde bulunan daha önce otizm tanısı konmuş yaşları 8 ve 13 arasında değişen (Ort ${ }_{\text {yaș }} \pm$ Ss; $\left.9.66 \pm 1.61\right) 12$ otizm spektrum bozukluğu tanısı olan çocuk (5 kız 7 erkek) katılmıştır. Ebeveyn onam formu alındıktan sonra, çocukların hepsi laboratuvara getirilmiştir. Test ortamı ve süreci tanıtıımıştır. Ebeveynlerin ve araştırmacı personelin teşvik ve yönlendirmesi ile gönüllük esasına göre bu çocuklardan sadece 4'ü motor performans ölçümlerine katılmıştır (2 kız ve 2 erkek). Motor performans ölçümüne katılan çocukların hepsinin yazı yazma ve el ile top atma sırasındaki tercihlerine göre sağlak oldukları tespit edilmiştir. Araştırmaya katılmadan önce çocukların ebeveynlerine katılım onay formu imzalatılmıştır. Araştırmada kullanılan yöntemler Nevşehir Hacı Bektaş Veli Üniversitesi Etik Kurulu tarafından onaylanmıştır. Araştırmaya katılan otizm spektrum bozukluğu tanısı olan çocukların araştırmaya katılmalarında sakınca olmadığı aynı zamanda Nevşehir Devlet Hastanesi Çocuk Psikiyatri Uzmanı ve Çocuk Gelişim Uzmanı tarafından da onaylanmıştır. Araştırma Dünya Tıp Birliği Helsinki Deklarasyonu'na uygun bir şekilde yapılmıştır.

Terapötik At Binme Aktiviteleri: Bu aktivitelere başlamadan önce, diğer bütün fiziksel aktivitelerde olduğu gibi terapötik at binme aktivitelerinin bir takım riskleri olabileceği yazılı ve sözlü olarak ebeveynlerle paylaşılmış ve onam formu alınmıştır. Aktiviteler sırasında bir çocuk gelişim uzmanı, bir çocuk psikiyatristi, bir fizik tedavi uzmanı ve terapötik at binme egzersizi yaptırabilecek sertifikaya sahip bir uzman, biniş merkezinde hazır bulunmuştur. Aktivitelere başlamadan önce binicilik merkezi ebeveynlere ve çocuklara tanıtılmıştır. Terapötik at binme uzmanının yanında atın sağ ve sol tarafında yürüyen ve ata liderlik eden 3 gönüllü aktivitelerde hazır bulunmuştur. Aktiviteler sırasında çocukların güvenliğinin sağlanması araştırma ekibinin önceliği olmuştur. Otizm spektrum bozukluğu tanısı olan çocuklar toplamda 8 hafta boyunca ve haftada 1 saat terapötik at binme aktivitesine katılmışlardır. Binicilik merkezinde her seansta sadece 1 çocuk aktivitelere katılmış ve yapılan aktiviteler her çocuk için ayrı ayrı organize edilmiştir. At binmeden önce ve sonra çocukların psikolojik olarak hazırlanması ve güvenlik kurallarını öğrenmeleri ve hatırlamaları amacıyla yapılan aktiviteler arasında; at tımar etme, yele ve kuyruk tarama, at süsleme, binicilik donatımlarını hazırlamaya yardım etme, at malzemelerini ayrı ayrı tanıma, atı ahırdan çıkartma ve içeri koyma, atı biniş platformuna yanaştırma, atın ayakıarını yıkama, ata el ile yem verme yer almıştır.

At binme sırasında yapılan egzersizler ise; at binme ve inme, doğru oturuş, dizgin tutma ve kullanma, at üzerinde sağa-sola ve öne-arkaya büst hareketleri, ellerle öne-arkaya, yanlara ve ayaklara uzanma hareketleri, kendisine gösterilen basılı resimlerin isimlerini söyleme, rakamları okuma, sağ ve sol elleri ile hedefe nesne atma, çocuk gelişim uzmanı ile diyalog geliştirme, üzengiye basarak ve basmadan ayağa kalkma, oturup kalkma, atın üzerine ileri ve geriye doğru uzanma ve yatma, elleri ile atı sevme, atın ön bacaklarına sağ ve sol el ile dokunmaya çalışma, atın yelesinden tutma olarak uygulanmıştır. Temel hedeflerin dışında ve ek olarak, çocuklar süreç sonunda at binme temel becerilerini kazanmışlardır (binme-inme, doğru oturuş, yürütme-durdurma).

Veri Toplama Araçları: Yaşam kalitesinin ölçülmesi için Çocuklar İçin Yaşam Kalitesi Ölçeği kullanılmıştır. Bu ölçek ebeveynler tarafından çocuklarının durumları göz önüne alınarak doldurulmuştur. Motor performans ölçümleri ise, çocukların bir hedefe işaret parmakları ile uzanma hareketini yaptıkları sırada gerçekleştirilmiştir. Burada temel olarak 2 parametreye bakılmıştır, hareketin hedeften 
ne kadar uzakta sonlandırıldığı ve hedefe ne kadar doğrusal gidildiğidir.

Yaşam Kalitesi ölçümü: Çocuklar İçin Yaşam Kalitesi Ölçeği (ÇiYKÖ), 2-18 yaş grubu çocuk ve ergenlerde kullanılan genel bir yaşam kalitesi ölçeğidir (Varni ve diğ., 1999). Ölçeğin 2-4, 5-7, 8-12 ve 13-18 yaş grubu özelliklerine göre anlatımı düzenlenmiş dört farklı formu bulunmaktadır. ÇiYKÖ; fiziksel, duygusal, sosyal ve okul ile ilgili işlevselliğin sorgulandığı dört alt bölümden oluşmaktadır. Ölçek değerlendirmesinde Fiziksel Sağlık Toplam Puanı (FSTP) ve duygusal, sosyal ve okul ile ilgili işlevselliğin toplamını oluşturan Psikososyal Sağlık Toplam Puanı (PSTP), Ölçek Toplam Puanı (ÖTP) kullanılabilmektedir. Yapılan bu araştırmada Fiziksel Sağlık Toplam Puanı (FSTP) ve Psikososyal Sağılı Toplam Puanı (PSTP) hesaplanmıştır.

Ölçekte beş seçenekli, Likert tipi gösterge çizelgesi kullanılmıştır ( 0 =hiçbir zaman, 1=nadiren, 2=bazen, 3=sıklıkla, 4=her zaman). Maddelerden alınan puanlar doğrusal olarak 0-100 puan arasında bir değere çevrilmiştir $(0=100,1=75,2=50,3=25,4=0) .0-100$ arasında değişebilen puanlar arttıkça yaşam kalitesi de artmaktadır (Varni ve diğ., 2001). çiYKO 2-4 ve 5-7 yaş grubu formlarının Türkçe geçerlilik ve güvenirliliği Üneri ve diğ. (2005) tarafından; ÇiYKO 8-12 ve 13-18 yaş grubu formlarının Türkçe geçerlilik ve güvenilirlik çalışması hem ergen formu hem de ebeveyn formu olamak üzere Cakin-Memik ve diğ. (Cakin-Memik ve diğ., 2007; Memik ve diğ., 2008) tarafından yapılmıştır. Yapılan bu çalışmada ise yalnızca ebeveyn formları kullanılarak OSB tanısı olan çocukların yaşam kaliteleri belirlenmiştir.

Motor Performans Ölçümü: Araştırmada otizm spektrum bozukluğu tanısı olan çocukların kolları ile uzanma hareketlerini ölçmek için Şekil 1'de görülen deney düzeneği kullanılmıştır. Bu sistem sanal bir şekilde kişinin gerçek hareketini ölçen bir sistemdir. Kişi yüksekliği ayarlanabilir sandalyeye oturtularak işaret parmak ucuna elektro manyetik sensör yerleştirilmiştir (TrackSTAR, Ascension Technology, USA).
Çocukların çene altı, deney düzeneğinde bulunan ayna hizasında olacak şekilde oturmaları sağlanmıştır. Bu durumda çocuklar rahat bir şekilde televizyondan ekrana yansıyan başlangıç noktası ve hedefi rahat bir şekilde görebilmişlerdir. Araştırmaya katılan çocukların sağ ve sol elleri ile ayrı ölçümler yapılmıştır. Bu sistemde uzanma hareketlerinin 2 boyutlu kaydı yapılmıştır. Çocukların kolları ile yaptıkları uzanma hareketlerini ölçmek için yatay olarak yerleştirilen 55" televizyondan hemen altında bulunan bir aynaya bir başlangıç noktası ve bir hedefin yer aldığı görüntü yansıtılmıştır. Çocukların kolları bu aynanın altında yer almaktadır. Çocuklar kollarını göremeseler de işaret parmak ucunun konumuna karşılık gelen $0.5 \mathrm{~cm}$ yarıçapında ve ortası artı işareti ile belirlenmiş bir imleci hareket ettirmeleri istenmiştir. Çocuk parmak ucunu hareket ettirdiği anda imleç ekranda hareket etmektedir. Yani gerçek zaman diliminde yapılan hareket ekrana yansıtılırken, işaret parmak ucu hareketi $100 \mathrm{~Hz}$ veri toplama hızı ile kaydedilmiştir. Görsel geri bildirim ve verilerin kaydedilmesi, motor performans ölçümüne özel olarak Matlab programında yazılan bir program aracılığı ile sağlanmıştır.

Motor performans ölçümlerinde çocuklara ekranda (aynada) bir başlangıç noktası (içi beyaz $1.5 \mathrm{~cm}$ yarıçapında daire) ve her defasında uzanma hareketini yapacakları bir hedef $(3 \mathrm{~cm}$ yarıçapında ve ortasında yer alan $1 \mathrm{~cm}$ yarıçaplı alanı mavi diğer alanı gri renkte olan daire) gösterilmiştir. Başlangıç noktası sternumdan $30 \mathrm{~cm}$ uzakta ve kullanılan ele göre $20 \mathrm{~cm}$ sol veya 20 $\mathrm{cm}$ sağa yerleştirilmiştir. Her zaman yalnızca 1 adet başlangıç noktası olmasına karşın, çocuklardan her defasında rastgele olarak üç farklı hedeften birisine uzanmaları istenmiştir (Şekil 2). Bu sistem gerçek zamanlı hareket ile bilgisayar oyunlarını birleştiren sistemlerle benzerlik taşımakla birlikte burada kişinin işaret parmağı ile yapmış olduğu uzanma hareketi 2 boyutlu olarak kayıt edilmektedir.

Verilerin Toplanması: Yaşam kalitesinin değerlendirilmesinde, Otizm spektrum bozukluğu 


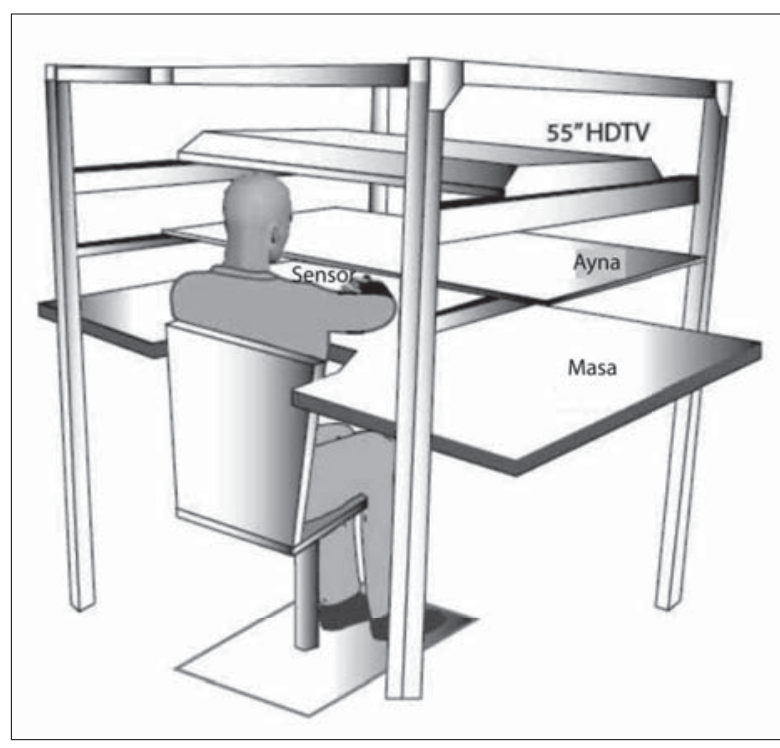

Şekil 1. Motor performans ölçümünde kullanılan düzenek.

tanısı olan çocukların ebeveynleri tarafından terapötik at binme aktivitesi başlamadan 1 gün önce ve bittikten 1 gün sonra çiYKÖ ebeveyn formu doldurulmuştur.

Motor performans ölçümlerinde, çocuklara gösterilen 3 hedef kullanılan ele göre başlangıç noktasının sol (sol el kullanııyorsa) ve sağ tarafı (sağ el kullanılıyorsa) olacak şekilde $30^{\circ}, 60^{\circ}$ ve $90^{\circ}$ lik açı ile herbiri başlangıç noktasına $20 \mathrm{~cm}$ uzaklıkta konumlanmıştır. Hedeflere tüm çocuklar rahatlıkla uzanabilmiştir. Harekete başlamadan önce hedefler çocuklara gösterilmiş, çocukIarın hareketi planlamaları için istedikleri kadar süre verilmiştir (çocuk kendi istediği zaman işaret parmağını hedefe götürmüştür). Çocuklar her 3 hedefe 10'ar kez uzanma hareketi yaparak toplamda da her iki elleri ile 30'ar kez uzanma hareketi gerçekleştirmişlerdir. Her bir el için yapılan ölçümler 4-5 dakika civarında sürmüştür. Çocuklar işaret parmak ucunu temsil eden imleci başlangıç noktasının içerisinde 300 ms tuttuklarında başlangıç noktasının rengi önce sarı ve ardından yeşil olmuş ve aynı zamanda işitsel olarak da "blink" sesi verilmiştir. Bu şekilde çocuklara harekete başlamaları için görsel ve işitsel uyaran verilmiştir. Çocuklar uyaranı takiben kendi istedikleri zaman hareketi başlatmışlardır. Çocukların harekete başlamaları ardından 3 sn süresince imleç hareketleri kayıt edilmiştir. Tüm çocuklar bu süre içerisinde hedefe ulaşmıştır.

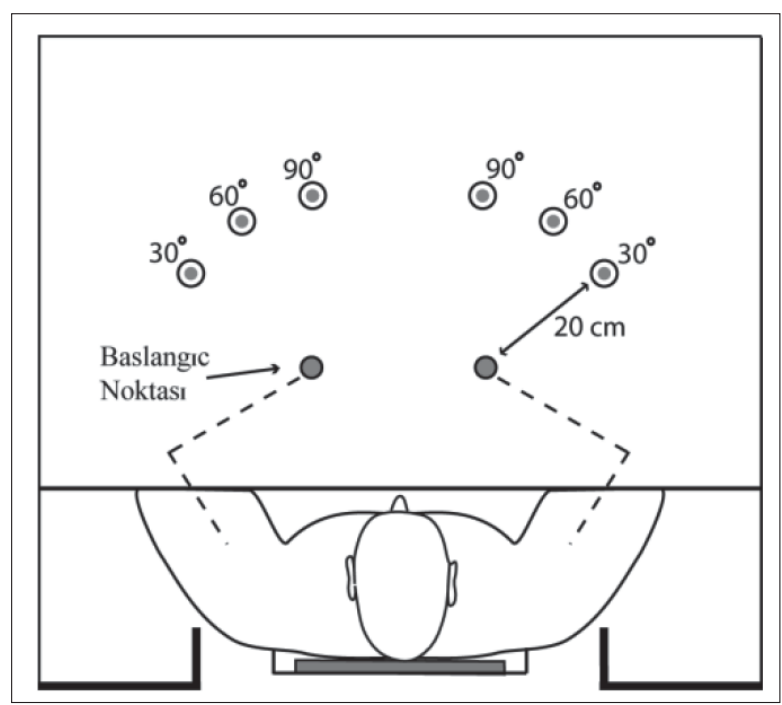

Şekil 2. Motor performans ölçümlerinde başlangıç noktası ve hedeflerin dağılımı.

Çocuklara deneye başlamadan önce 3 ile 5 tekrar arasında deneme yaptırılarak sisteme alışmaları sağlanmıştır. Çocuklar bu testi terapötik at binmeye başlamadan 1 gün önce ve bittikten 1 gün sonra uygulamışlardır. Ölçümler Nevşehir Hacı Bektaş Veli Üniversitesi Motor Kontrol Laboratuvarında yapılmıştır.

Verilerin Analizi: ÇiYKÖ'nün hesaplanabilmesi için Veri Toplama Araçları bölümünde açıklanan hesaplama yöntemi kullanılmıştır. Böylece, Fiziksel Sağlık Toplam Puanı (FSTP) ve Psikososyal Sağlık Toplam Puanı (PSTP) hesaplanmıştır.

Motor performans analizinde ise, yapılan uzanma hareketindeki kinematik performansı hesaplamak için çocukların uzanma hareketini ne kadar doğru ve ne kadar doğrusal yaptığına bakılmıştır. Doğruluk $(\mathrm{cm})$, hareketin bittiği nokta ile hedefin merkezi arasındaki mesafenin hesaplanması ile ölçülmüştür. Yani hareketin bittiği noktanın hedefin merkezine olan uzaklığı olarak hesaplanmıştır. Bu değer ne kadar düşükse, doğruluk o kadar yüksektir. Doğrusallık ise, hareketin başlangıç ve bitişi arasındaki en fazla sapmanın, hareketin başlangıç noktası ile bittiği nokta arasındaki doğruya en düşük sapma miktarına oranlanmasıyla hesaplanmıştır. Başlangıç ve bitiş noktaları arasındaki referans kabul edilen doğrusal çizgiden uzaklaşma, sapma olarak kabul edilir. Bu uzaklaşma ne ka- 
dar fazlaysa sapma o kadar büyük değer alır. Doğrusallık sıfıra ne kadar yakınsa, kişi o kadar düzgün doğrusal bir hat üzerinde gitmiş demektir. Çocukların her yapmış olduğu uzanma hareketi için bu değişkenler Matlab yazılımı kullanılarak hesaplanmıştır. Terapötik at binme aktivitesine toplamda 12 Otizm Spektrum Bozukluğu (OSB) tanısı olan çocuk katılmasına rağmen, ilgili motor performans ölçümleri bu çocuklardan yalnızca 4'ü (2 kız ve 2 erkek) ile yapılabilmiştir. Diğer 8 OSB tanısı olan çocuk ölçüm için laboratuvara gelmelerine karşın, ölçümü yapmak istememişlerdir. Bunun yanında OSB tanısı olan çocuklardan 1 tanesi ön-test sırasında sağ eli ile 30 denemeden sadece 13 denemeyi yapabilmiştir. Ancak aynı çocuk son-test sırasında 30 denemeyi de çok rahat yapabilmiştir. Bu çocuğun ön-test sırasında yapmış olduğu 13 denemenin her hedef için ortalaması alınarak analize dahil edilmiştir. İstatistik analiz öncesinde yapılan ön değerlendirmede, bazı çocukların hem ön-test (toplamda 32 deneme) hem de son-test sırasında (toplamda 34 deneme) normal olmayan (uzanma mesafesi $20 \mathrm{~cm}$ olmasına karşın, $10 \mathrm{~cm}$ üzerinde hata yapılan) denemeler yaptıkları tespit edilmiştir. Bu denemeler istatistik analize dahil edilmemiştir. $\mathrm{Bu}$ nedenle motor performans ölçümüne katılan çocukların toplamda yaptıkları 30 denemeden bazıları çıkartıımış ve geriye kalan denemelerin de her bir çocuk ve her bir hedef için ortalamaları alınmıştır. Dolayısıyla, her bir çocuğa ait 2 adet ön test (sağ-sol el ve $30^{\circ}, 60^{\circ}$ ve $90^{\circ}$ lik hedefler), 2 adet son-test (yine sağ-sol el ve $30^{\circ}, 60^{\circ}$ ve $90^{\circ}$ lik hedefler) değerleri elde edilmiştir.

İstatistiksel Analizler: ÇiYKÖ'nün iki alt boyutu için ön-test ve son-test puanlarının karşılaştırılmasında tekrarlı ölçümlerde $t$-testi kullanılmıştır. Motor performans ölçümleri sadece 4 çocuktan alındığından, ön-test ve sontest doğruluk ve doğrusallık değerleri arasındaki farklılıkları tespit etmek için non-parametrik test olan Wilcoxon T Testi (Wilcoxon signed-rank test) kullanılmıştır. Bu test her bir el, 2 değişken ve her bir hedef için ayrı ayrı yapılmıştır. Dolayısıyla toplamda 12 farklı karşılaştırma yapılmıştır.
Hareket hızının hareket doğruluğu üzerine etkisi olduğundan (Fitts, 1954), ön-test ve son-test doğruluk ve doğrusallık değerleri arasındaki farklılıklara bakılmadan önce, bu testlerdeki denemeler arasında farklılık olup olmadığına da bakılmıştır. Bunun için yine Wilcoxon T Testi kullanılmıştır. İstatiksel analizlerde IBM SPSS Statistics 21 programı kullanımıştır. İstatistiksel anlamlılık düzeyi .05 olarak belirlenmiştir.

\section{BULGULAR}

Yaşam Kalitesi: Çocuklar İçin Yaşam Kalitesi Ölçeği (ÇiYKÖ) değerlendirmesinde Fiziksel Sağlık Toplam Puanı (FSTP) ve Psikososyal Sağlık Toplam Puanı (PSTP) hesaplanmıştır. PSTP için yapılan istatistik analizinde, öntest (Ort \pm Ss: $40.25 \pm 13.08$ ) ve son-test (Ort \pm Ss: $54.16 \pm 24.97$ ) puanları arasında istatis tiksel olarak anlamlı fark bulunmuştur, $\mathrm{t}_{(11)}=-2.75$, $p=.02$. Çocukların PSTP değerleri son testte istatistiksel olarak anlamlı bir şekilde artmıştır. FSTP için ön-test (Ort \pm Ss: $66.16 \pm 19.59$ ) ve sontest (Ort \pm Ss: $82 \pm 22.59$ ) puanları arasındaki fark da istatistiksel olarak anlamlı bulunmuştur, $\mathrm{t}_{(11)}=-2.75, \mathrm{p}=.02$. FSTP değerleri istatistiksel olarak anlamlı bir şekilde son-test'te artmıştır. Genel olarak yaşam kalitesi bakımından, çocukların hem fiziksel hem de psikososyal alanlarda gelişim gösterdikleri söylenebilir.

Motor Performans: Sağ ve sol el hız, doğruluk ve doğrusallık değerlerinin her bir hedef için ayrı ayrı ön-test ve son-test değerlerinin karşıIaştırılmasında Wilcoxon T Testi kullanılmıştır.

Hız değişkenin ön-test ve son-test için ölçüm sonuçları Şekil 3'te verilmiştir. Şekil 3'ten de anlaşılacağı gibi, testler ve hedefler arasında hareket hızı açısından çok fazla bir farklılık olmamasına karşın, son testteki hareketlerin az da olsa daha hızlı oldukları söylenebilir. El ve hedeflerin herbiri için ayrı ayrı yapılan istatistiksel analiz sonuçlarında, hem sol hem de sağ el için ön-test ve son-test hareket hız değerlerinde istatistiksel olarak anlamlı bir farklılığa rastlanmamıştır ( $p>$.05). Dolayısıyla, hareket hızının doğruluk ve doğrusallık performanslarına bir etki etmediği söylenebilir. 


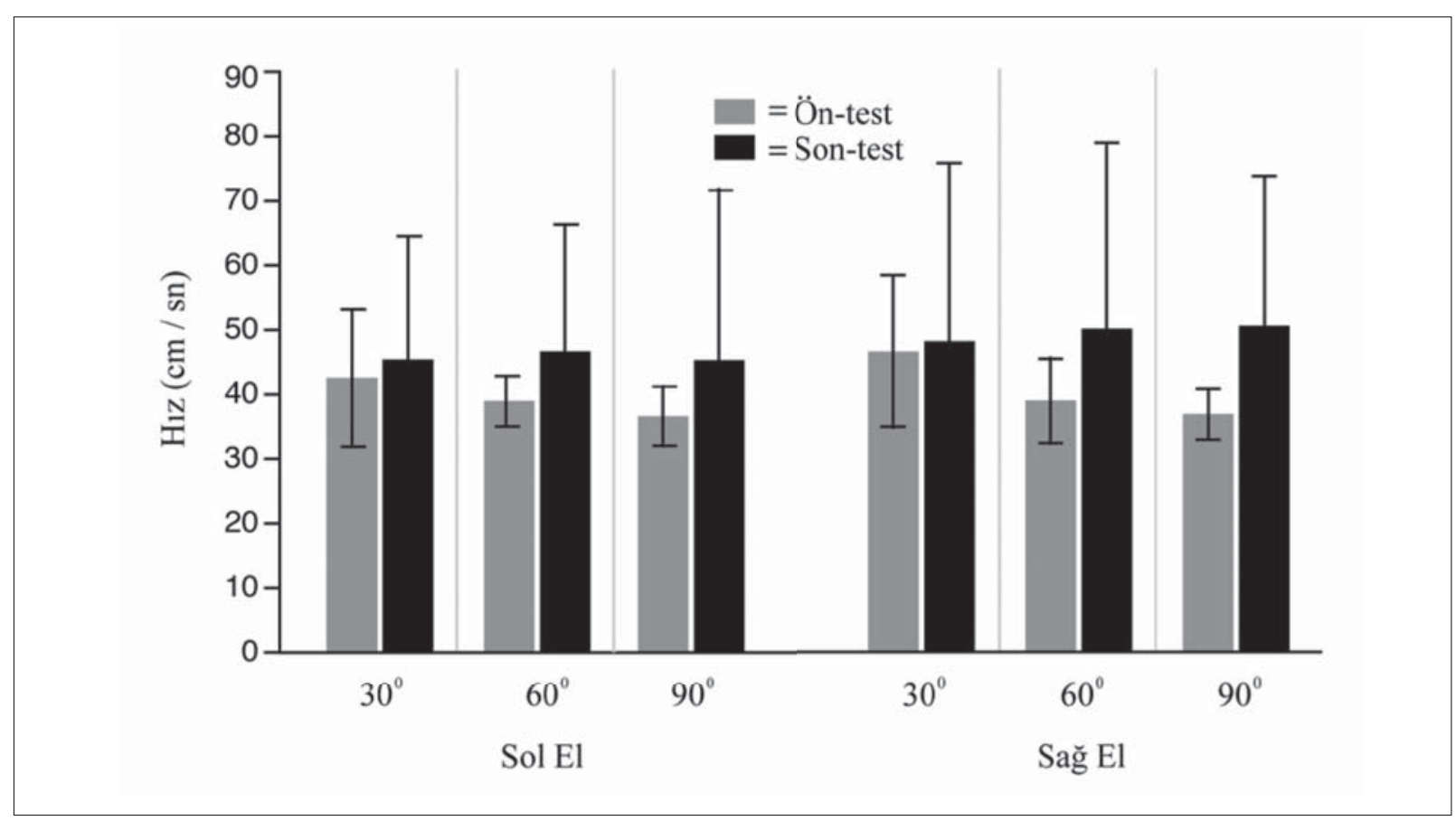

Şekil 3. Sol ve sağ el ile yapılan uzanma hareketi sırasındaki ön-test ve son-test hız değerleri.

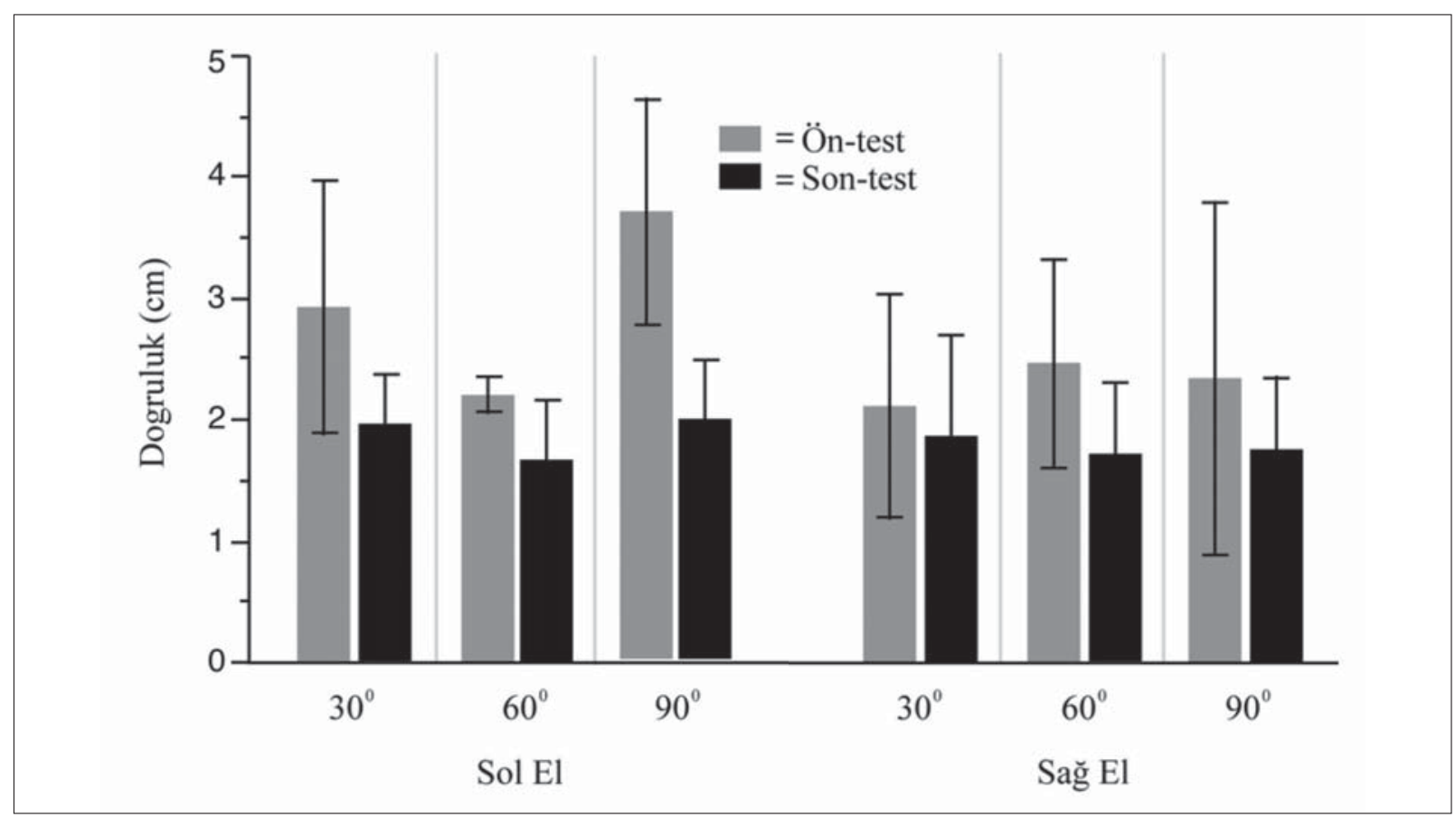

Şekil 4. Sol ve sağ el ile yapılan uzanma hareketi sırasındaki ön-test ve son-test doğruluk değerleri.

Doğruluk ile ilgili ölçüm sonuçları Şekil 4'te sunulmuştur. Şekil 4'te görüleceği gibi çocuklar sol elleri ile $90^{\circ}$ de bulunan hedefe uzanma hareketi yaptıklarında, son testte (Ort \pm Ss: $1.98 \pm$ 0.47) ön teste göre (Ort \pm Ss: $3.69 \pm 0.92$ ) çok daha iyi bir performansa sahip oldukları görülmektedir. 90'deki hedef için sol el doğruluk değerleri ile ilgili yapılan istatistiksel analiz so- nucunda, ön-test ve son-test arasında istatistiksel olarak anlamlı farklılık olmamasına karşın, anlamlıık değeri .05'e çok yakın çıkmıştır ( $Z=1.83, p=.06$ ). 900'deki hedef için sağ el doğruluk değerleri ile ilgili yapılan istatistiksel analiz sonucunda, ön-test ve son-test arasında istatistiksel olarak anlamlı farklılık bulunmamış$\operatorname{tır}\left(Z=0.73, p>\right.$.05). 60 $0^{\circ}$ deki hedef için sağ ve 


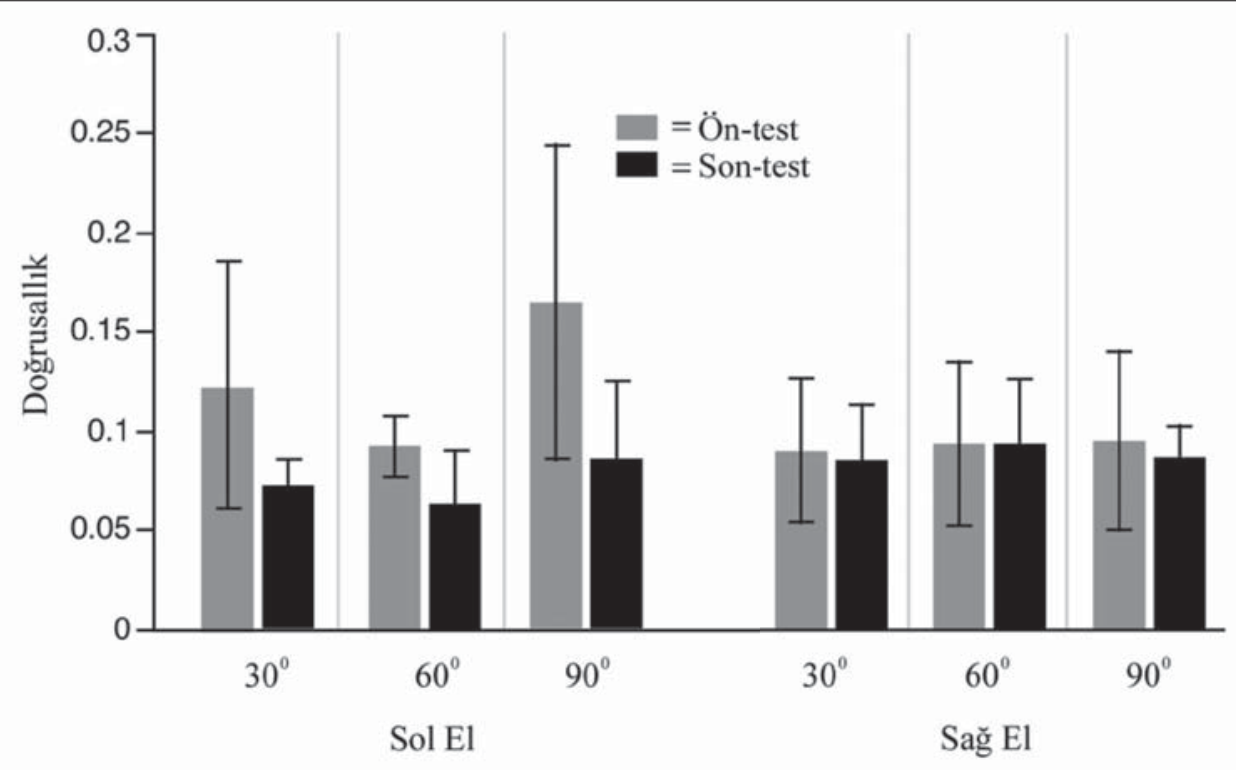

Şekil 5. Sol ve sağ el ile yapılan uzanma hareketi sırasındaki ön-test ve son-test doğrusallık değerleri.

sol el doğruluk değerleri ile ilgili yapılan istatistiksel analizler sonucunda, ön-test ve son-test arasında istatistiksel olarak anlamlı farklılık bulunmamıştır (Sağ el: $Z=0.36, p>.05$ ve Sol el: $Z=0.14, p>.05)$. Yine $30^{\circ}$ deki hedef için sağ ve sol el doğruluk değerleri ile ilgili yapılan istatistiksel analizler sonucunda, ön-test ve son-test arasında istatistiksel olarak anlamlı farklılık bulunmamıştır (Sağ el : $\boldsymbol{Z}=0.14, \boldsymbol{p}>.05$ ve Sol el: $Z=0.14, p>$.05).

Doğrusallık ile ilgili ölçüm sonuçları Şekil 5 'te gösterilmiştir. Doğruluk değerlerine benzer olarak, çocuklar özellikle $90^{\circ}$ de bulunan hedefe uzanma hareketini yaptıklarında, son testte (Ort \pm Ss: $0.16 \pm 0.08$ ) ön teste göre (Ort \pm Ss: $0.08 \pm 0.04)$ daha doğrusal hareket yaptıklarını görmekteyiz. $90^{\circ}$ deki hedef için sol el doğrusallık değerleri ile ilgili yapılan istatistiksel analiz sonucunda, ön-test ve son-test arasında istatistiksel olarak anlamlı farklılık olmamasına karşın, anlamlılık değeri .05'e çok yakın çıkmıştır $(Z=1.82, p=.06) .90^{\circ}$ deki hedef için sağ el doğrusallık değerleri ile ilgili yapılan istatistiksel analiz sonucunda, ön-test ve son-test arasında istatistiksel olarak anlamlı farklııı bulunmamış$\operatorname{tır}\left(Z=0.0, p>\right.$.05). $60^{\circ}$ deki hedef iç in sağ ve sol el doğrusallık değerleri ile ilgili yapılan istatistiksel analizler sonucunda, ön-test ve son-test arasında istatistiksel olarak anlamlı farklılık bu- lunmamıştır (Sağ el: $Z=0.0, p>.05$ ve Sol el : $Z=1.09, p>$.05). Yine $30^{\circ}$ deki hedef için sağ ve sol el doğrusallık değerleri ile ilgili yapılan istatistiksel analizler sonucunda, ön-test ve son-test arasında istatistiksel olarak anlamlı farklılık bulunmamıştır (Sağ el : $Z=0.36, p>.05$ ve Sol el : $Z=1.46, p>$.05)

$\mathrm{Bu}$ sonuçlara göre otizm spektrum bozukluğu tanısı olan çocukların terapötik at binme aktivitelerinden sonra özellikle $90^{\circ} \mathrm{de}$ bulunan hedefe yapılan uzanma hareketinde sol elleri ile daha iyi performans gösterdikleri görülmektedir. İstatistiksel olarak 90'ye yapılan uzanma hareketlerinin ön-test ve son test değerleri arasında anlamlı farklılık bulunmaması büyük ölçüde motor performans ölçümlerine katılan çocuk sayısının sınırlı olmasından kaynaklanabilir. Ancak yine de çalışmaya katılan grup özel bir grup olduğundan, ön-test ve son-test değerleri arasındaki farklıık özellikle 90'ye yapılan uzanma hareketlerinde gözle görülebilir düzeydedir.

\section{TARTIŞMA}

Bu çalışmada terapötik at binme aktivitesinin otizm spektrum bozukluğu (OSB) tanısı olan çocuklardaki yaşam kalitesi ve motor performans düzeyleri üzerine olan etkileri araştırılmıştır. Yaşam kalitesi, fiziksel sağlık toplam puanı (FSTP) ve psikososyal sağlık toplam puanı (PSTP) 
üzerinden hesaplanmıştır. Motor performans ise, çocukların bir hedefe işaret parmakları ile uzanma hareketini yaptıkları sırada ölçülmüştür. Motor performans değerlendirilmesi için hareketi ne kadar doğru ve doğrusal yaptıkları ile ilgili değerlere bakılmıştır. Motor performans ile ilgili sonuçlara bakıldığında, terapötik at binme aktivitelerinden sonra çocukların özellikle sol el doğruluk ve doğrusallık performanslarının 90'ye yapılan hedefe uzanmalarda geliştiği söylenebilir. Bu hedefe yapılan uzanma hareketleri sırasında omuz ve dirsek eklemleri hareketi birlikte gerçekleştirmektedir. $30^{\circ}$ ve $60^{\circ}$ ye yapılan uzanma hareketlerinde de omuz eklemi hareketin kontrolü sırasında az da olsa aktif olmasına karşın, bu hedeflere yapılan hareketler çoğunlukla dirsek eklemi tarafından kontrol edilmektedir (Sainburg ve Kalakanis, 2000). Dolayısıyla $90^{\circ}$ de bulunan hedefe yapılan hareketler, $30^{\circ}$ ve $60^{\circ}$ ye yapılan hareketlerden biraz daha fazla koordinasyon gerektirebilir. Yani hareketi gerçekleştirmek diğer hedeflere göre daha zor olabilir. Bu durum eklemlerdeki serbestlik derecesinden kaynaklanabilir. Bir eklemdeki serbestlik derecesi ne kadar fazla ise, o eklemin kontrolü de güçleşmektedir. Omuz eklemindeki serbestlik derecesi 3 ve dirsek eklemindeki serbestlik derecesi 1'dir (Rose, 1997). 90॰de bulunan hedefe yapılan hareketlerdeki serbestlik derecesi artı̆̆̆ından, bu hareketin yapılması diğer hedeflere göre zorlaşmaktadır (Sainburg ve Kalakanis, 2000). At binme aktiviteleri çocukların el-göz koordinasyonu, denge (Zadnikar ve Kastrin, 2011), yürüme, koşma ve sıçrama gibi kaba motor becerilerde (Sterba ve diğ., 2002) artış sağladığından dolayı; bu çalışmada olumlu artış görülen doğruluk ve doğrusallık performanslarının bu motor yeteneklerdeki gelişime bağlı olduğu düşünülmektedir.

Sağlak olan kişiler sağ elleri ile herhangi bir nesneye yapmış oldukları uzanma hareketlerini (bir bardağa uzanma ve tutma gibi) daha beceri ile gerçekleştirdiklerinden, sol ellerini günlük yaşantılarında çok fazla kullanmamaktadırlar (Gabbard ve Helbig, 2004). Ön testte çocukların sol el doğruluk ve doğrusallık performanslarının düşük çıkmasının bununla bağlantısı olabilir. Halbuki, at binme sırasında çocukların dizginleri her iki elleri ile kontrol etmesi ve aktiviteler boyunca her iki ellerini kullanarak yaptıkları farklı aktivitelerin çocukların uzanma becerilerini geliştirmiş olması muhtemeldir. Bu nedenle, at binme egzersizlerinde her iki kolun eşit olarak çalıştırılmasının, son-test performansının yükselmesini sağladığı düşünülmektedir.

Araştırma sonucunda yaşam kalitesi ile ilgili FSTP ve PSTP puanlarının son-test ölçümlerinde daha yüksek olduğu bulunmuştur. Bu da otizm spektrum bozukluğu tanısı olan çocukların terapötik at binme aktivitelerinden sonra hem fiziksel hem de psikososyal boyutta olumlu yönde gelişim gösterdikleri şeklinde yorumlanabilir. Bu sonuç, alan yazındaki diğer ebeveyn formu kullanılarak yapılan çalışmaların sonuçları ile paralellik göstermektedir (Bass ve diğ., 2009; Borgi ve diğ., 2016; Memishevikj ve Hodzhikj, 2010). Örneğin, Bass ve diğ. tarafından (2009) yapılan çalışmada terapötik at binme aktivitelerinin OSB tanısı olan çocuklarda sosyal motivasyonu arttırdığı ve otistik seviyeyi az da olsa düşürdüğü bulunmuştur. Terapötik at binme aktiviteleri sırasında çocuk ve at arasında bir etkileşim olmakta, bu da çocukta pozitif sosyal davranışlar gelişmesine ve kendine olan güveninin artmasına yardımcı olmaktadır. Çocuğun tek başına ata binme aktivitesini yapması bile, yaptıkları işe motive olmalarını sağlamaktadır. Konuşma becerisi çok iyi olmayan çocuk dahi, ata durması veya hareket etmesi için "Ohoo" veya "yanak şaklatma" gibi sesler çıkardığında durmasını veya hareket etmesini sağlayınca, çocuğun kendine olan güveni artmaktadır. Bu da çocuktaki otizm spektrum bozukluğunun hastalık şiddetini azaltabilmektedir (Grundtvig Projesi, 2014). Yapılan bu araştırmadaki terapötik at binme aktivitelerinde çocukların bu sesleri çıkartarak atı hareket ettirmeleri veya durdurmaları sağlanmıştır. Bunun sonucunda da OSB tanısı olan çocukların psikososyal davranışlarında olumlu yönde gelişmeler olduğu ebeveyn formlarında tespit edilmiştir. 
Teraötik at binme aktivitelerinin motor ve nörolojik rahatsızlıkların (ör. serebral palsi, çoklu sikleroz, omurga yaralanmaları) rehabilitasyonunda; sosyal, duygusal ve fiziksel alanlarda pozitif etkisinin olabileceği belirtilmektedir (Freund ve diğ., 2011). Atın yapmış olduğu ritmik hareketlere uyum sağlamak durumunda olan kişilerde; denge, kas simetrisi, koordinasyon ve doğru postür alışkanlığı gelişsmektedir (Bronson ve diğ., 2010; Tseng ve diğ., 2013). Bu tür gelişimlerin farklı bir hastalık türü olan otizm spektrum bozukluğunda da gözlenebileceği belirtilmiştir (Borgi ve diğ., 2016).

Alan yazında terapötik at binme aktivitelerinin OSB tanısı olan çocuklardaki motor performans veya yeterlilikleri üzerine yapılmış çok fazla çalışma bulunmamaktadır. Wuang ve diğ. (2010) tarafından yapılan araştırmada simülasyon aracılığı ile yapılan at binme aktivitelerinin OSB tanısı olan çocuklarda motor yeterlilikler üzerine olan etkilerine bakılmıştır. Motor yeterlilikleri ölçmek için Bruininks-Oseretsky Motor Yeterlilik Testi kullanmışlardır. Araştırma sonucunda simulasyon yöntemiyle at binme egzersizi yapan otizm spektrum bozukluğu tanısı olan çocukların motor yeterliliklerinde (koşma hızı, çabukluk, denge, çift tarafı koordinasyon gibi) artış görüldüğü bulunmuştur (Wuang ve diğ., 2010). Borgi ve diğ. (2016) tarafından yapılan bir diğer araştırmada, terapötik at binme aktivitelerinin OSB tanısı olan çocuklardaki sosyal fonksiyonlar ve motor yetenekler üzerine olan etkileri incelenmiştir. Araştırmacılar sosyal fonksiyon ve motor yetenekleri ölçmek için Vineland Adaptif Davranış Ölçeğini kullanmışlardır. Araştırma sonucunda terapötik at binme aktivitelerinin sosyal fonksiyon düzeyinde yüksek düzeyde bir artış ve bunun yanında motor yeteneklerde orta düzeyde bir artış sağladığını bulmuşlardır (Borgi ve diğ., 2016). Bu sonuçlar araştırmamı bulgularıyla benzerlik göstermektedir. Hem kullanılan ölçek verilerinde hem de fiziksel olarak yapılan motor performans ölçümlerinde terapötik at binme aktiviteleri sonrasında gelişme gözlemlenmiştir.

$\mathrm{Bu}$ araştırmada uzanma becerisinin değerlendirilmesi, bilgisayar oyunlarına benzerliği nedeniyle çocukların ilgisini çekebilmiştir ve çocukların bu beceri ile ilgili motor performansları değerlendirilmiştir. Alan yazında motor performansın değerlendirildiği deneysel araştırmalar sınırlıdır (Borgi ve diğ., 2016). Ancak yaptığımız bu araştırmada motor performans ölçümüne katılan çocuk sayısının az olması sonuçların genele yansıtılması açısından sınırlıık taşımaktadır. İnsanların günlük işlerinde ellerini çok sayıda beceride ve sıklıkla kullandıkları varsayıldığından, özellikle koordinasyon ve dikkat problemi olan OSB tanısı olan çocuklarda terapötik at binme aktivitelerinden sonra uzanma becerilerinin geliştirilmesi bu çocukların motor fonksiyonlarını arttırmalarını sağlayacaktır.

\section{SONUÇ VE ÖNERILER}

Bu araştırma sonucunda, terapötik at binme aktivitelerinin otizm spektrum bozukluğu tanısı olan çocuklarda hem psikososyal yönden (12 çocukta) hem de motor performans yönünden (4 çocukta) ilerlemeler sağladığı bulunmuştur. Genellikle hekimler ve uzman sağlık personeli tarafından kullanılan rehabilitasyon yöntem ve tekniklerin yanında terapötik at binme aktivitelerinin de otizm spektrum bozukluğu tanısı olan çocuklarda rehabilitasyon yöntemi olarak kullanımı yaygınlaştırılmalıdır. Bazı ülkelerde devlet destekli ve farklı hasta gruplarına ücretsiz olarak hizmet veren "terapötik at binme" merkezlerinin ülkemizde de faaliyete geçmesi ve yaygınIaşması teşvik edilmelidir. Bunun yanında, terapötik at binme egzersizi yaptıracak yeterlilikte ve çalıştırıcı sertifikasına sahip uzman sayısının da arttırılması önerilmektedir.

Bu araştırmada otizm spektrum bozukluğu tanısı olan çocuklara 8 hafta boyunca her hafta 1 saat terapötik at binme aktivitesi uygulanmıştır. Yapılacak olan diğer çalışmalarda özellikle bu sürenin arttırılması sağlanabilir ve böylelikle aktivitelerin etkileri daha iyi gözlemlenebilir. Ayrıca, sadece ön-test ve son-test ölçümlerinin değil, ara ölçümlerin yapılması da beklenen faydaların gelişim sürecinin belirlenebilmesi açısından önemlidir. Aynı zamanda yapılacak yeni araştırmalarda çalışma grubunun sayısının art- 
tırılması ve kontrol grubunun da eklenmesi sonuçların genellenebilirliğini arttıracaktır.

Yazar Notu: Bu araştırmaya katılan tüm ailelere ve çocuklara teşekkür ederiz. Bunun yanında araştırma ortamını hazırlayan Nevşehir Devlet Hastanesi Baş Hekimi sayın Dr. Yücel ŞAL'a teşekkürlerimizi borç biliriz.

\section{Yazıșma Adresi (Corresponding Address):}

Yrd. Doç. Dr. Selçuk AKPINAR

Nevşehir Hacı Bektaş Veli Üniversitesi, Eğitim

Fakültesi, Beden Eğitimi ve Spor Eğitimi Bölümü

E-posta: selcukbos@gmail.com

Telefon No: 03842281000 / 21011

Faks No: 03842281040

\section{KAYNAKLAR}

1. APA (American Psychiatric Association). (2013) Diagnostic and statistical manual of mental disorders (DSM-5®). American Psychiatric Association Publishing .

2. Ayres AJ. (1979). Sensory integration and the child. LoS Angeles: Western Psychological Services.

3. Ayres AJ, Tickle LS. (1980). Hyperresponsivity to touch and vestibular stimuli as a predictor of positive response to sensory integration procedures by autistic children. The American Journal of Occupational Therapy, 34, 375-381.

4. Barak Y, Savorai O, Mavashev S, Beni A. (2001). Animal-assisted therapy for elderly schizophrenic patients: A one-year controlled trial. The American Journal of Geriatric Psychiatry, 9(4), 439-442.

5. Bass MM, Duchowny CA, Llabre MM. (2009). The effect of therapeutic horseback riding on social functioning in children with autism. Journal of Autism and Developmental Disorders, 39(9), 1261-1267.

6. Borgi $M$, Loliva $D$, Cerino $S$, Chiarotti F, Venerosi A, Bramini M, ve diğ. (2016). Effectiveness of a standardized equine-assisted therapy program for children with autism spectrum disorder. Journal of Autism and Developmental Disorders. 46: 1-9.

7. Bronson $\mathbf{C}$, Brewerton $\mathbf{K}$, Ong J, Palanca $\mathbf{C}$, Sullivan SJ. (2010). Does hippotherapy improve balance in persons with multiple sclerosis: A systematic review. European Journal of Physical and Rehabilitation Medicine, 46, 347-353.

8. Cakin-Memik N, Agaoglu B, Coskun A, Uneri OS, Karakaya I. (2007) The validity and reliability of Turkish Pediatric Quality of Life Inventory in 13-18 years old Turkish children. Türk Psikiyatri Dergisi;18:353-363.

9. Case-Smith J. (1991). The effects of tactile defensiveness and tactile discrimination on in-hand manipulation. The American Journal of Occupational Therapy., 45, 811-818.

10. Cherng RJ, Liao HF, Leung HWC, Hwang AW. (2004). The effectiveness of therapeutic horseback riding in children with spastic cerebral palsy. Adapted Physical Activity Quarterly, 21, 103-121.

11. Copetti F, Mota CB, Graup S, Menezes KM, Venturini EB. (2007). Angular kinematics of the gait of children with Down's syndrome after intervention with hippotherapy. Revista Brasileira de Fisioterapia, 11, 6, 503-507.
12. Fitts PM. (1954). The information capacity of the human motor system in controlling the amplitude of movement. Journal of Experimental Psychology; 47:381-391.

13. Freund LS, Brown OJ, Huff PR. (2011). Equine-assisted activities and therapy for individuals with physical and developmental disabilities: An overview of research findings and the types of research currently being conducted. In P. McCardle, S. McCune, J. A. Griffin, L. Esposito, \& L. S. Freund (Eds.), Animals in our lives: Human animal interaction in family, community and therapeutic settings. Baltimore: Paul H. Brookes.

14. Gabbard C, Helbig CR. (2004). What drives children's limb selection for reaching in hemispace? Experimental Brain Research, 156, 325-332.

15. Grundtvig Project. (2014). 'Taught me How to Walk' Developed between Italy, Greece,Turkey and Croatia,Copyprint S.n.c.-Centro Copia Stampa.

16. Katcher AH, Wilkins GG. (1998). Animal-assisted therapy in the treatment of disruptive behavior disorder in childhood. In A. Lundberg (Ed.), The environment and mental health (pp. 193-204). Mahwah, NJ: Lawrence Erlbaum Associates, Inc.

17. Koomar JA, Bundy AC. (2002). Creating direct intervention from theory. In A.C. Bundy, S.J. Lane, \& E.A. Murray (Eds.), Sensory integration: Theory and practice (2nd ed., pp. 294-296). Philadelphia: F.A. Davis.

18. Memik NÇ, Ağaoğlu B, Coşkun A, Üneri öş, Karakaya I. (2008) The validity and reliability of the Turkish pediatric quality of life inventory for children 8-12 years old. Turkish Journal of Child and Adolescent Mental Health; 15:87-99.

19. Memishevikj H, Hodzhikj S. (2010). The effects of equineassisted therapy in improving the psychosocial functioning of children with autism. Journal of Special Education and Rehabilitation, 11(3-4), 57-67.

20. Mulligan S. (1998). Patterns of sensory integration dysfunction: A confirmatory factor analysis. The American Journal of Occupational Therapy., 52, 819828.

21. O'Haire ME. (2013). Animal-assisted intervention for autism spectrum disorder: A systematic literature review. Journal of Autism and Developmental Disorders, 43(7), 1606-1622.

22. Developmental dyspraxia. In A. Bundy, E. Murray, \& S. Lane (Eds.), Sensory integration: Theory and practice (2nd ed., pp. 71-100). Philadelphia: F.A. Davis. 
23. Rose, DJ. (1997). A Multilevel Approach to the Study of Motor Control and Learning. Needham Heights: Allyn \& Bacon.

24. Rothe EQ, Vega BJ, Torres RM, Soler SM, Pazos RM. (2005). From kids and horses: Equine facilitated psychotherapy for children. International Journal of Clinical and Health Psychology, 5(2), 373-383.

25. Rutter M (2005). "Incidence of autism spectrum disorders: changes over time and their meaning". Acta Paediatrica, 94 (1): 2-15.

26. Sainburg RL, Kalakanis D. (2000). Differences in control of limb dynamics during dominant and nondominant arm reaching. J Neurophysiol, 83: 26612675.

27. Schmidt RA, Lee TD. (2005). Motor control and learning (4th ed.). Champaign, IL: Human Kinetics Services.

28. Snider L, Korner-Bitensky N, Kammann C, Warner S, Saleh M. (2007) Horseback Riding as Therapy for Children with Cerebral Palsy. Physical \& Occupational Therapy In Pediatrics, 27:2, 5-23.

29. Smith IM. (2004). Motor problems in children with autistic spectrum disorder. In D. Dewey \& D.E. Tupper (Eds.), Developmental motor disorder: A neuropsychological perspective (pp. 152-168). NewYork: The Guilford Press.

30. Sterba JA, Rogers BT, France AP, Vokes DA. (2002). Horseback riding in children with cerebral palsy: effect on gross motor function. Developmental Medicine \& Child Neurology, 44: 301-308.

31. Teitelbaum $\mathbf{P}$, Teitelbaum $\mathbf{0}$, Nye J, Fryman J, Maurer RG. (1998). Movement analysis on infancy may be useful for early diagnosis of autism. Proceedings of the National Academy of Sciences of the United States of America, 95, 13982-13987.

32. Tseng SH, Chen HC, Tam KW. (2013). Systematic review and meta-analysis of the effect of equine assisted activities and therapies on gross motor outcome in children with cerebral palsy. Disability and Rehabilitation, 35(2), 89-99.

33. Üneri Ö. (2005). Çocuklar için Yaşam Kalitesi Ölçeği'nin 2-7 Yaşlarındaki Türk Çocuklarında Geçerlik ve Güvenilirliği. Yayınlanmamış Uzmanlık Tezi, Kocaeli Üniversitesi Tıp Fakültesi.

34. Varni JW, Seid M, Kurtin PS. (2001) PedsQLTM 4.0: reliability and validity of the Pediatric Quality of Life Inventory version 4.0 generic core scales in healthy and patient populations. Medical Care; 39:800-812.

35. Varni JW, Seid M, Rode CA. (1999). The PedsQL: measurement model for the pediatric quality of life inventory. Medical Care, 37: 126-139.

36. Wang PS, Aguilar-Gaxiola S, Alonso J, Angermeyer MC, Borges G, ve diğ. (2007). Use of mental health services for anxiety, mood, and substance disorders in 17 countries in the WHO world mental health surveys. The Lancet, 370, 9590: 841-850.
37. Wuang YP, Wang CC, Huang MH, Su CY. (2010). The effectiveness of simulated developmental horse-riding program in children with autism. Adapted Physical Activity Quarterly, 27, 113-126.

38. Yıldırım Şık $M$, Çekmece Ç, Dursun $N$, Dursun E, Balıkçı E, Altunkanat Z, Gülcü MA. (2012). Is Hypotherapy Beneficial for Rehabilitation of Children with Cerebral Palsy? Türkiye Klinikleri Journal of Medical Science, 32(3): 6011-608.

39. Zadnikar M, Kastrin A. (2011). Effects of hippotherapy and therapeutic horseback riding on postural control or balance in children with cerebral palsy: a meta-analysis. Dev Med Child Neurol; 53: 684-91. 